\title{
Modernization of Agriculture and Use of Information and Communication Technologies by Farmers in Coastal Yogyakarta
}

\author{
Subejo ${ }^{1,2}$, Dyah Woro Untari ${ }^{1}$, Ratih Ineke Wati ${ }^{1}$ and Gagar Mewasdinta ${ }^{1}$ \\ ${ }^{1}$ Study Program of Extension and Agricultural Communication, Department of Agricultural Socio-Economics, \\ Faculty of Agriculture, Universitas Gadjah Mada, Indonesia \\ ${ }^{2}$ Center for Economic and Public Policy Studies (CEPPS), Universitas Gadjah Mada, Indonesia
}

Received: 2019-02-12 Accepted: 2019-11-17

\section{Keywords: \\ modernization \\ information, \\ communication, \\ access, \\ farmer, \\ coastal}

Correspondent Email: subejo@ugm.ac.id

\begin{abstract}
In the development process, Information and Communication Technologies (ICTs), which also commonly referred to as electronic media or cyber media have been acknowledged as a new instrument that could facilitate the need of new information and innovation for rural people or farmers. However, several studies reported that extension and communication basedelectronic media in developing countries encounter more problems rather than in developed countries. This research aims to investigate the ownership, access, utilization or functions of ICTs for obtaining information supporting the daily life of farmers and for promoting various farming activities in the coastal area of Kulon Progo Regency Yogyakarta. The research method of the study was a descriptive method that has been conducted by a mixed method. The study found that in line with modernization in agriculture, farmers have been using conventional and new electronic media including television, radio and mobile phone with function for getting new information. Conventional electronic media are still dominant while the use of new electronic media has been gradually increasing. Information gathered from ICTs includes social, cultural, economic, health and environmental issues. The use of new electronic media particularly the internet via smartphone has newly started to be utilized among farmers in the coastal farming area who intensively engaged in horticulture crops cultivation mainly for getting and exchange the market information. Information on technological innovation is still dominant among farmers. Better infrastructure and mobility access, improvement of telecommunication network and development of content and format of information provided by new media will be prospective in the future.
\end{abstract}

(0) 2019 by the authors. This article is an open access article distributed under the terms and conditions of the Creative Commons Attribution(CC BY NC) licensehttps://creativecommons.org/licenses/by-nc/4.0

\section{Introduction}

Various supports for improving the performance and contribution of the agricultural sector in Indonesia still should be prioritized. In the development process in the Indonesian context, the role of the agricultural sector still very important, therefore high attention still needs to be addressed to the agricultural and rural sectors. As it has been reported by Harini, Susilo and Nurjani (2015), the agricultural sector is the main economic activity of the society in Indonesia and also the source of people economy strengthening and the priority direction of the development of the agricultural sector should be appropriately arranged including appropriate innovations and technologies.

Improvement of the rural sector and agricultural development in Indonesia has also been greatly influenced by the implementation of the decentralization policy, which started in 1999. The policy has influenced the process of rural and agricultural transformation, people mobilization and human access on various innovations and needed information (Bunnell, 2009).
In the progress of the global development process including in rural areas, the use of mass media for information delivery related to agricultural and rural development has been gradually increasing. The use of printedmedia, suchasmagazinesandnewspapers, widely spread across farming communities. Furthermore, the penetration of electronic media, such as cyber extension (extension through information technology media, also called information and communication technologies) has significantly expanded. To some extent, the function of printed and electronic media has overcome the backwardness of technology by focusing on rural and agricultural information and innovation dissemination.

FAO (2019) and Wiki NUS Edu (2019) have conceptualized that Information and Communication Technologies (ICTs) is a broader term for Information Technology (IT), which refers to all communication technologies, including the internet, wireless networks, cell phones, computers, software, middleware, videoconferencing, social networking, and other media 
applications and services enabling users to access, retrieve, store, transmit, and manipulate information in a digital form. ICT is the integration of information processing, computing and communication technologies. ICT covers any product that will store, retrieve, manipulate, transmit or receive information electronically in a digital form and is concerned with these products

While Khan, et.al, (2010) and Khan (2013) proposed that as a new type of innovation in agricultural and rural sector, practices and implementation of ICTs for supporting agriculture are widely understood to include the use of radios, televisions, audio recordings, video recordings, telephones, the internet, and mobile phones or smartphones to deliver various agricultural information. With regard to media access, Leeuwis (2013) argued that access to particular media depends on the different characteristics of farmers. This because each channel requires particular resources such as device, skills, knowledge, time, facilities, permit and cost.

The most common studies on ICTs have focused on macro and micro perspectives. Very few studies pay attention to the mezzo perspective of ICTs application. In addition to focus on macro and micro perspectives, studies on ICTs also commonly gave priority only on the internet application. Several studies on macro perspectives of ICTs have been done by Mahant, et al., (2012) and Singh, et al., (2017) on use and role of ICT in agriculture, Lokeswari (2016) on the use of ICT among farmers, Saidu, et al., (2017) on opportunity and challenges of ICT application in agriculture and Purnomo and Lee (2010) on the assessment of readiness and barriers on ICT implementation in agriculture. While Ugwuishiwu et.al, (2012) has conducted several studies on micro perspectives of ICTs, on application ICT in crop production, Gultom, et al., (2016) on the role of ICT for strengthening horticulture farmers and Setiowati, et al., (2015) on the effect of ICT adoption on marketing capability of business actors.

Media and information access is closely related to the opportunity for improvement of productivity in the economic and agricultural sectors. To access important information via electronic media, farmers need tools, such as a television, computer, radio, mobile phone, smartphone or other media devices, which are considered relatively expensive. In some cases, farmers who have occasional access to the media are unwilling or unable to utilize it. Electronic media is mostly used for entertainment and has a lesser impact on enhancing the knowledge, attitude and behavior of farmers to support their farming productivity. The type of information content and format for displaying information are very important to be considered appropriate for improving the access of farmers on ICTs (Subejo, 2016).

A study on ICTs use has been getting developed especially related to economic activity-commerce, political and social aspects. ICT research focuses on connectivity and inclusion of rural groups over urban groups on the market (Salemink, Strijker and Bosworth, 2017). In the economic and social aspects, ICT in rural areas allows the communities to access information sources to increase their production, become literate in electronic media and generate sharing media for communities (Soriano, 2007).

However, only a limited number of studies on ICT access in rural Indonesia, especially dealing with the agricultural sector exist. ICT implementation experiences hindrances that are farmers' unpreparedness, technological and organizational cultures of the extension agency, extension area and extension agent age (Purnomo \& Lee, 2010). The cyber extension supports farming effectively by giving fast information to the farmers (Amin, Sugiyanto, Sukesi and Ismad, 2013). Besides, the key factors of using agricultural electronic service are channel used in the service, service's cash flow and maximization of user benefits (Sulthoni, Laksono, Ishiura, Amemiya and Umejima, 2013).

The use of ICTs in rural Indonesia has been also promoted by the Indonesian government which also has been supported by many related parties. A report by the Ministry of Communication and Information of the Republic of Indonesia (2015) shows that, at a national level, ICT access and ownership by farmers have been considerably high for television, mobile phones, and radio. While access to the internet by farmers was still relatively low. The use of new electronic media such as the internet for supporting practical economic activities of rural and farming communities is likely still limited as also reported on a study in rural Central Java by Guntoro, Subejo and Sazali (2016). While a study by Das, et al., (2016) reports that among 20 surveyed countries, the mobile broadband price in Indonesia is considerably low, but internet bandwidth and average connection speed are also at a low level.

A study by Subejo (2016) concludes that even though at a global level, the prospect of ICTs for agricultural development is essential, the fact remains that only a limited number of farmers can access electronic media. People in some remote areas in Indonesia are not supported by appropriate ICT infrastructure and have low levels of access to cellular phone and internet connections, broadcast networks (for television and radio) and even electricity.

Therefore, research on the access and utilization of ICTs by farmers in the rural areas of Indonesia will be greatly important. This research considers the geographical conditions, socio-economic characteristics, literacy rates and skills of the farmers on their ability to access and use media for agriculture. In the study site, Bugel Village, Panjatan District, Kulon Progo Regency, Yogyakarta has plenty of coastal sandy farming lands and coastal farming area for long years has been referred to as a marginal farming area. However, since the 1980s, the coastal sandy farming 
lands have been gradually improved into a more productive farming area.

In general, coastal sandy farming lands locally known as common resources which belong to Paku Alam Ground and Sultan ground (abandoned coastal land which formally belongs to Yogyakarta royal family), and rural farming households for a long time have directly managed the land resources to be used for cultivating various farming crops. Various efforts in coastal sandy farming land have been undertaken to increase the income of coastal communities. Better access to transportation and communication including ICTs to some extent have influenced to the improvement of practices of coastal farming management.

Furthermore, this research aims to investigate the ownership, access, utilization or functions of ICTs for supporting the daily life of farmers and for promoting various farming activities in the coastal area of Kulon Progo Regency, Yogyakarta.

\section{The Methods}

The research site was in the farming community of coastal area Bugel Village, Panjatan District, Kulon Progo Regency, Yogyakarta. Bugel Village has been chosen as a research site by considering the great improvement in commercial horticultural farming development since the end of the 1980s which marked by the changing from the marginal-coastal farming area into a productive farming area. In addition, since Bugel Village is located in a flat coastal area, it has easy access to socio-economic aspects and the electricity and telecommunications networks have also developed rapidly.

The study has been done in the nature of descriptive analytics. Neuman (2009) argued that the descriptive method is a method that can be used to analyze groups of people, objects, systems of thinking and certain classes of events in the present that are described systematically and accurately based on facts, and then the relationship characters among the phenomena can be explored.

The approach of research is combining of qualitative and quantitative approaches, which is called the mixed-method (Creswell and Clark, 2010). The use of mixed-method was for combining advantage from each method and to reduce disadvantages from each method.

For collecting needed quantitative data, the interview session was undertaken by using the census method for farming group members with a total of 25 respondents from Bugel Village, Panjatan District, Kulon Progo Regency. Those people were active members who represent farmers in farming coastal areas.

In addition to quantitative data collected from all respondents, qualitative data were also collected through in-depth interviews with key informants including farmer group leader, community leader and manager of the chili auction market. The selection of informants of the research considered their access to information and their experience in developing agricultural production in each area. An in-depth interview was performed to determine more specific data in the surveyed area. The data collected (quantitative and qualitative data) were analyzed using categories, matrices, proportion, statistic descriptive and qualitative descriptions.

\section{Result and Discussion}

\section{General Condition of Research Sites}

In general, characteristics of socio-economic aspects and geographical conditions include farming patterns, area conditions, cropping patterns, accessibility, infrastructure, communication network, and dominant economic activities. The location of the surveyed site is shown in Figure 1.

Farmers' accessibility to the farming land is adequate, as the majority of farming roads are asphalted, with only a few of the farming roads constructed with stone and soil. The research site of Kulon Progo is relatively distant from the downtown (approximately $34 \mathrm{~km}$ ). Agricultural production mostly includes horticultural crops such as chili and eggplant and some fruit crops such as watermelon, melon, and Californian papaya. The horticultural commodity prices from produce planted in Kulon Progo were, on average, higher than the price of the paddy or corn. The paddy or corn price ranged between 3,000.00-7,000.00 IDR per $\mathrm{kg}$, while the horticultural commodities, especially chili, could reach 10,000.00-60,000.00 IDR per kg. In general, the price of horticultural products has been higher as compared to food crops. A key informant Mr. Skr (59 years old) mentioned that due to the prospective and profitable chili farming, since the last few years many young people started farming on the coastal farming area, even some university graduates.

Although the farmland in the coastal areas of Kulon Progo is classified as marginal sandy land with considerably low fertility for agricultural production, the hard work of the farmers in managing the coastal sandy farmland since the 1980s has converted the soil into more productive land for agricultural activities. Farmers have started to grow chili and other horticulture crops such as string beans and other vegetables.

\section{Characteristics of Farming Households}

In addition to the characteristics of the research site, it is important to understand the characteristics human resource aspect. General characteristics of farmer respondents encompass age, formal education, type of occupation, farming experience, number of household members, and farming household income. The brief description of each characteristic of the respondents is presented in Table 2 . 


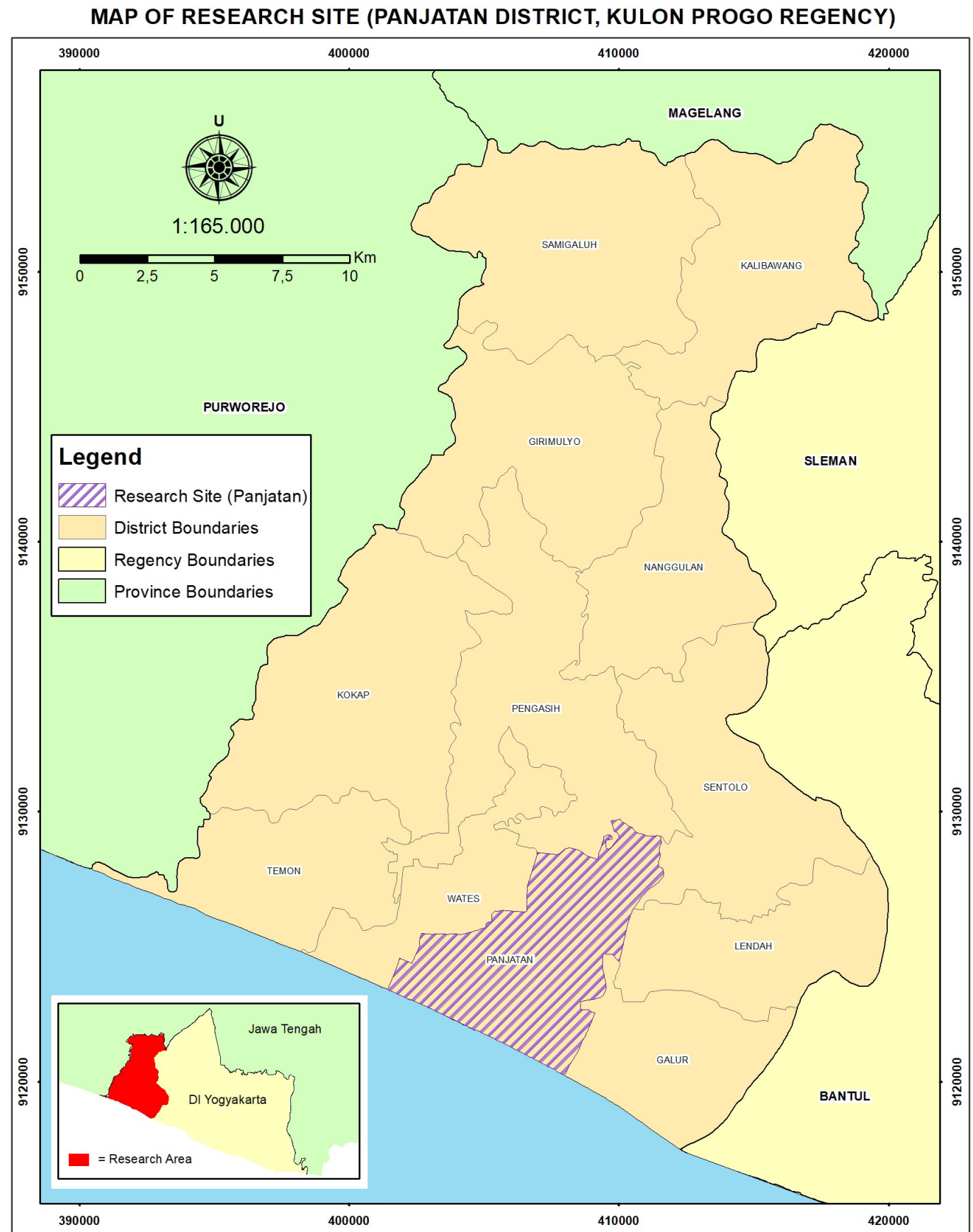

Figure 1. Map of Research Site (Panjatan District, Kulon Progo Regency)

(Source: http://di-yogyakarta.blogspot.com/2010/08/profil-kabupaten-kulon-progo.html)

Table 1. General Conditions of the Research Site

\begin{tabular}{ll} 
Characteristics & Description \\
Farming Pattern & Horticulture crops and fruits \\
Area condition & Coastal sandy land \\
Cropping pattern & Whole of year \\
Accessibility (distance from the city center) & $34 \mathrm{~km}$ \\
Infrastructure (road condition) & Mainly asphalted, some parts constructed by stone \\
Communication Network & Well developed \\
Economic activities of the rural population & The agricultural sector and related activities are dominant \\
\hline
\end{tabular}


Table 2. Characteristics of Farming Households

\begin{tabular}{lrr}
\hline Characteristics of respondent & Person & \\
\hline Age (yeas old) & 17 & 68.00 \\
$31-50$ & 8 & 32.00 \\
$51-70$ & 0 & - \\
$>70$ & & 12.00 \\
Formal education & 3 & 28.00 \\
Elementary school & 7 & 56.00 \\
Junior high school & 14 & 4.00 \\
Senior high school & 1 & 100.00 \\
University & & 00.00 \\
Type of occupation & 25 & 60.00 \\
Farming only & 0 & 36.00 \\
Farming and non-farming & & 4.00 \\
Farming experience (years) & 15 & \\
$21-20$ & 9 & 4.00 \\
$21-35$ & 1 & 40.00 \\
$>35$ & & 56.00 \\
Household member (person) & 10 & 48.00 \\
$<3$ & 12 & 12.00 \\
$3-5$ & 3 & \\
$>5$ & 10 & \\
Household monthly income & & \\
$<3.000 .000$ IDR & & \\
$3.000 .000-6.000 .000$ IDR & & \\
\hline * 1 (US $\$=00.000$ IDR 12,000 IDR (Indonesian Rupiah) & \\
\hline
\end{tabular}

Age. In the research site, $68 \%$ of respondents were categorized as 31-50 years old. A better generation of farmers are present in the coastal area of Kulon Progo. Since it was established in the early 1980s, the agricultural land has plenty of coastal sandy farmland that is being managed by the second generation (farmers between 31-50 years old), so one could suggest that the farmers' regeneration in this area was quite successful.

Formal Education. The extent of formal education for the farmers in the research site was high school (56\% of the respondents were high school graduates). Moreover, $4 \%$ of the respondents graduated with a diploma.

Type of Occupation. Farming activities is very important for determining the economic status of farming households. Most farmers have a high dependency on farming activities. Job opportunities in the non-farming sector are still considerably limited in the research site.

Farming Experience. In the research site, $60 \%$ of the farmers had only $0-20$ years of farming experience (and, thus were relatively a young generation of farmers). Commercial horticulture farming in the coastal areas has been very attractive for not only original farming families but also for newcomers who have no farming activities experience before.
Household Member. In general, the size of household members among farming households was small. The larger proportion of farming households have household members between 3 and 5 persons (48\%). An only a small portion of farming households have members over 5 persons (12.00\%).

Farming Household Income. The average income of farming households was 3.928.840 IDR per month. The larger proportion of farming households $(56,00 \%)$ have an average monthly income over 3.000.000 IDR. Due to the higher income, these farmers could fulfill primary, secondary and even tertiary needs.

\section{Modernization of Coastal Agriculture}

Through an in-depth interview with community leaders and farming group leaders, information on the historical aspect of area development and agricultural development has been collected. Historically, before 1980, the research site was characterized by coastal area has been referred to as a marginal farming area. Only very few crops could be cultivated and produced very low agricultural crop productivity. Therefore farming household income in the site was very low and in many cases, the incidence of poverty was very high among rural people. In addition to farming activities, the 
opportunity for getting non-farming activities on the site was also very limited. As a result, many members of farming households in the site temporary migrated to the city or even to the outer islands such as Sumatera and Kalimantan for getting various jobs such as construction workers, housekeepers, factory laborers, palm oil estate workers, etc. Several cases of farming household members became a migrant workers in Malaysia as oil palm estate laborers. One of the key informants is Mr. Sd (60 years old) stated that starting in the early 2000s many villagers who migrated to the city and outer island returned to the village to do chili farming because they listened to the success stories of chili farming managed by farmers on their native village of the coastal area.

Modernization of agriculture in the area has been started from the 1980s, thanks to pioneering initiative actions and farming innovations of the several farmer leaders, marginal sandy land in a coastal area can be managed into productive farming land for various agricultural products. Developing coastal sandy areas as productive farming land has been regarded as an appropriate solution for land conversion and small size of land ownership through a long process and mechanism. Some talented farmers have started to plant in the coastal sandy farming land since the 1980s. They were successful to convert the coastal sandy farming land into more productive land which used for agricultural cultivation and production.

Furthermore, pioneering works of innovative farmers have attracted the other farmers to join in the process. The process also gave an opportunity to farmers who have little access to farming land. Then, farmers could join to produce various agricultural crops in coastal sandy farming land so-called open access.

As has been reported by Supriyanto, et al.,. (2013), the development of new type of productive coastal farming system has been initiated by local innovators such as Mr. Sukarman and Mr. Sudiro and later on it has been supported by office of agriculture of Kulon Progo District, Research Team from Universitas Gadjah Mada, researchers from Agricultural Technology Agency Yogyakarta-Ministry of Agriculture, local NGOs and private corporations in agriculture.

Several eminent innovations related to agricultural activities which significantly have improved farming productivity cover coastal land consolidation, efficient irrigation system by using shallow well and pipe system, selection of suitable crops, planting of particular tress as windbreaker, using plastic mulch for preventing from weed and reducing water evaporation, improvement of sandy land quality by adding organic manure, development of farm road for transporting manure, horticultural products, introduction efficient auction market (especially for chili).

Farmers commonly have been cultivating commercial horticultural crops which include chili, eggplant, watermelon, watermelon, Californian papaya, and tomato. The most favorite horticultural crop which has been grown among farmers was chili. Even though the price of horticultural crops grown by farmers was commonly fluctuated, however in average farmers have been getting higher income.

High productivity of horticultural crops and higher income of farming households have been remarkably improving the economic status of farming households in the site. As a result of farming modernization; lifestyle, education level, housing facilities, and transportation access among rural people in the site have been notably changing into better conditions.

Modernization of agricultural practices in the coastal areas has been accompanied by rural area development. The site was very close to south-south road network (national road project for connecting southern part of Java), therefore the transportation facilities have been improving very well. In line with transportation infrastructure development, some development projects also remarkably improved such as telecommunication networks and electricity networks.

Various development projects occurred in the site which naturally as flat-coastal areas have been greatly facilitating better mobility of rural people, better communication access and creating better conditions for transporting and marketing agricultural products. Better accessibility and higher mobility of rural dwellers have been reducing transaction costs and increasing the higher efficiency of agribusiness activities.

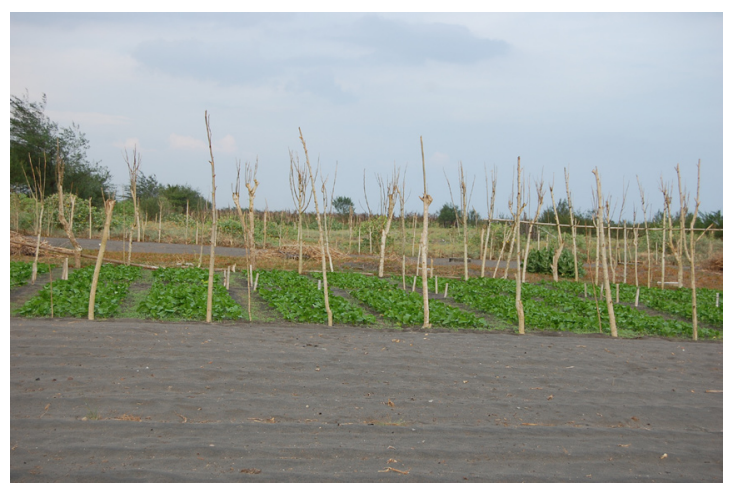

Figure 1. The initial stage of sandy farming land development in the coastal area

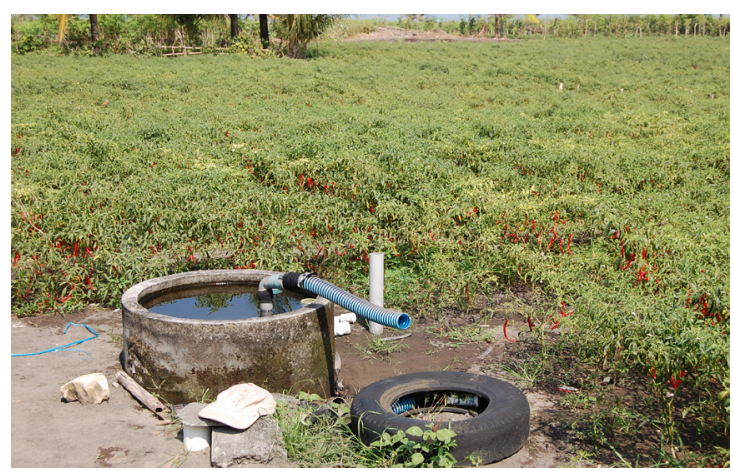

Figure 2. Construction of shallow well and pipe connection for crops watering 


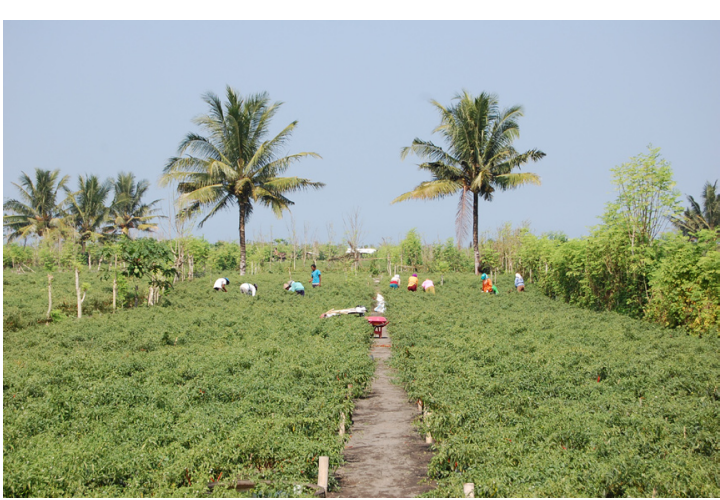

Figure 3. Land consolidation and planting of particular trees as wind breaker

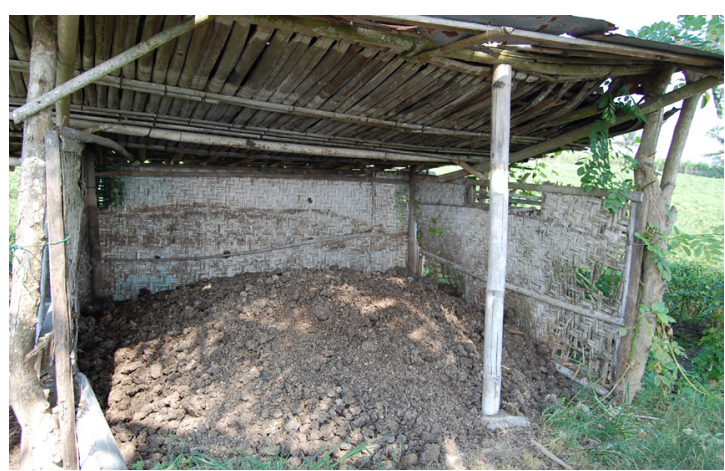

Figure 4 . Land quality improvement by adding organic manure

\section{Media Ownership by Farmers}

The definition of media ownership by farmers refers to the media owned by farmers (bought by farmers rather than lending or accessing it from others).

Electronic media is referred to as several types of electronic hardware, such as televisions, radios, mobile phones, smartphones, the internet via a PC or laptop, and VCDs or DVDs, and printed media is referred to as several types of paper-based media such as newspapers, bulletins, and magazines. The proportion of media ownership (including electronic and printed media) to some extent depicts the farmers' access and utilization pattern for using media to obtain information and other needs for the farmers' daily life (see Table 3 ).
Based on the level of media ownership, it can be categorized into 4 namely: Very high (76-100\%), High (51-75\%) Medium (26-50\%), Low (0-25\%). Table 3 shows that very high ownership of media by farming households was for television and mobile phone (over $80 \%$ ). While the high media ownership category (51$75 \%$ ) among farming households was for smartphones and radio. The ownership of the other media was categorized as medium (PC/laptop and CV/DVD) and low (newspaper and magazine).

By grouping the media into electronic and printed media, Table 3 shows that the majority of the farmers had more electronic media ownership than printed media ownership. The percentage of electronic media ownership, such as televisions, radios, mobile phones, smartphones, PCs/laptops, CDs/DVDs in Kulon Progo was greater than printed media, such as newspapers and magazines, which only reached $16 \%$ and $8 \%$, respectively. Printed media (magazines in particular) had the lowest percentage of ownership in the research site.

\section{Functions of Electronic Media}

Theoretically, purposes of the use of electronic media by farmers and their household members in their daily life can be categorized as for (1) entertainment, (2) education, and (3) obtaining various information. In this study purpose of media, use has been focused on obtaining various needed information.

The farming household members access the electronic media by private ownership of the media and/or by borrowing from other parties, such as friends, neighbors, relatives, or colleagues, and by accessing the media from public facilities.

In fact, not all of the farmers who have media ownership privately preferred to use the media for accessing information. In general, farmers have used not only conventional electronic media but also new electronic media. Based on the number of media user for obtaining information, mobile phone and television were very important sources of various information. The use of media by farmers for accessing information is displayed in Table 4.

Table 3. Rank and Category of Media Ownership in the Research Site

\begin{tabular}{clrl}
\hline Rank & Media Type & The owner $(\%)$ & Category $\left(^{*}\right)$ \\
\hline 1 & Television & 100.00 & Very High \\
2 & Mobile phone & 80.00 & Very High \\
3 & Smartphone & 64.00 & High \\
4 & Radio & 60.00 & High \\
5 & PC/laptop & 48.00 & Medium \\
6 & CD/DVD & 32.00 & Medium \\
7 & Newspaper & 16.00 & Low \\
8 & Magazine & 8.00 & Low \\
\hline
\end{tabular}

Note: $\left(^{*}\right)$ Low (0-25\%), Medium (26-50\%), High (51-75\%), Very high (76-100\%), 
Based on the proportion of media use for accessing information as compared to media users, the big proportion of media use as a mobile phone, smartphone, laptop/PC and television.

While looking at the proportion of media use for information as compared to total surveyed farmers, it can be displayed that mobile phone and television were categorized as high by proportion $64,00 \%$ and $60,00 \%$ respectively. The mobile phone has been shared among rural people in the coastal area and can be used for accessing various needed information especially using short message service and making the call. Among villagers have been using mobile phones for getting and exchanging various daily information either for social or economic aspects. In the research site, the mobile phone is relatively new media used among farmers which introduced since the 2000s in line with the improvement of rural transportation and telecommunication network development.

Farmers stated that the television could provide up-to-date information that could fulfill the needs of farmers, leading to the preference of the TV over other media. A key informant Mr. Skr (59 years old) explained that almost all houses have television, which in addition to being used as a medium of entertainment and to search for news is also used to find information related to agriculture.

Smartphone use for accessing information can be categorized as at medium level (28,00\%). In addition, the price of smartphone and cost of the internet data package is still relatively expensive; the application menu and technical use of smartphone is also more complicated. Therefore, the older generation of farmers was not easy to use a smartphone. A key young informant Mr. Sut (36 years) states that at least in the last 10 years most farmers have owned mobile phones and some young farmers also have smartphones. Initially, a smartphone was used for social purposes, hobbies and entertaining, but later on, it was used to support agricultural activities through searching on information technologies, horticulture product prices and related agricultural news.

The use of radio was at a low level at the research site. Radio as conventional electronic media has been used from the 1970s in line with the modernization process in the rural life of Indonesia. However, the popularity of radio has been gradually decreasing in line with the development of new alternative media in rural areas.

Aspects of electronic media usage for accessing various information can be categorized into several categories, including social, cultural, economic, political, health, and the environment. Table 5 describes the access and utilization of electronic media for searching for various needed information.

Generally, the tendency for electronic media usage was for accessing information related to social and cultural issues, economics, and the environment. Topics about social issues included society life, a pilgrimage to Mecca, localization issues, eviction, narcotics or liquor abuse, formal education for children, and others. Information pertaining to cultural issues included concerns for current issues such as local arts, talk shows, quizzes, films, and drama series. Information on economic issues included the current price of agricultural commodities, Indonesian exports, imports on agricultural commodities, and local economic growth. Aspects related to environmental information encompassed floods, landslides, earthquakes, bad weather, and current climate change issues.

A high percentage of electronic media usage for accessing information, especially for social, cultural, and environmental aspects, closely correlated with high social sensitivity, keeping the tradition and awareness of the environment and society.

\section{ICTs Use for Supporting Agricultural Related Operations}

Farmers use electronic media for accessing information and issues related to agricultural activities. Agricultural information is categorized into the following 6 topics: (1) technical production, (2) marketing, (3) policy, (4) success stories, (5) human interest stories, and (6) financing access.

Based on the rank of electronic media usage for supporting agricultural related activities, several electronic media, including televisions, radios, and mobile phones, are noted as important media for farmers. The farmers assumed that conventional electronic media especially television could present upto-date information related to technical production, marketing, policy, success stories, human interest stories, and finance through various programs aired every day (see Table 6). While radio has been perceived as important media for delivering information related to marketing information and agricultural production issues.

Mobile phone usage for marketing ranks higher than for technical production support. Agricultural activity based on horticultural production by farmers in Kulon Progo made farmers demand a quick transaction because horticulture crops are naturally perishable and need to be sold quickly. The mobile phone's benefits of shortmessage service(SMS) and phonecall facilities were helpful for assisting farmers in marketing horticultural products and connecting producers with buyers. While the use smartphone is still limited, however, is getting important among horticulture farmers especially for accessing information on agricultural technologies and marketing. The smartphone is also used by particular farmers for accessing information related to policy, success stories, human interest stories and financing.

However, based on the number of electronic media usage for agriculture percentage (rank 1 of 4 of every aspect), the results showed that the farmers had a higher tendency to use electronic media for accessing 
Table 4. Functions of Electronic Media for Obtaining Information

\begin{tabular}{lccrrrl}
\hline $\begin{array}{c}\text { Types of } \\
\text { Media }\end{array}$ & $\begin{array}{c}\text { User of } \\
\text { media } \\
\text { (person) (a) }\end{array}$ & $\begin{array}{c}\text { Use for } \\
\text { Information } \\
\text { (person) (b) }\end{array}$ & $\begin{array}{c}\text { \% use for } \\
\text { information by } \\
\text { media user (a/b) }\end{array}$ & $\begin{array}{c}\text { \% user for } \\
\text { information by total } \\
\text { households (25) }\end{array}$ & $\begin{array}{c}\text { Rank of } \\
\text { Use for } \\
\text { Information }\end{array}$ & $\begin{array}{c}\text { Category } \\
\left({ }^{*}\right)\end{array}$ \\
\hline Mobile phone & 17 & 16 & 94.12 & 64.00 & 1 & High \\
Television & 25 & 15 & 60.00 & 60.00 & 2 & High \\
Smartphone & 8 & 7 & 87.50 & 28.00 & 3 & Medium \\
Radio & 14 & 5 & 35.71 & 20.00 & 4 & Low \\
Laptop/PC & 3 & 2 & 66.67 & 0.00 & 5 & Low \\
CD/DVD & 4 & 0 & 0.00 & 0.00 & 6 & Low \\
\hline
\end{tabular}

Note: ${ }^{*}$ ) Low (0-25\%), Medium (26-50\%), High (51-75\%), Very high (76-100\%)

Table 5. Farmers' Access and Utilization of Electronic Media Based on the Type of Information (\% User)

\begin{tabular}{clrrrrrr}
\hline Rank & Types of Media & \multicolumn{1}{c}{ Social } & Cultural & Economic & \multicolumn{1}{c}{ Politics } & Health & Environment \\
\hline 1 & Television & 92.00 & 88.00 & 64.00 & 68.00 & 76.00 & 92.00 \\
2 & Mobile phone & 28.00 & 12.00 & 16.00 & 8.00 & 16.00 & 20.00 \\
3 & Radio & 32.00 & 0.00 & 24.00 & 4.00 & 4.00 & 4.00 \\
4 & Smartphone & 28.00 & 52.00 & 16.00 & 16.00 & 24.00 & 28.00 \\
5 & CD/DVD & 0.00 & 12.00 & 0.00 & 0.00 & 0.00 & 0.00 \\
6 & Laptop/PC & 4.00 & 4.00 & 0.00 & 0.00 & 4.00 & 4.00 \\
\hline
\end{tabular}

Note: percentage of user represents the comparison number of media user compared with total surveyed farmers and one type of media can be used for multiple types of function/utilization

Table 6. Electronic Media Usage Based on Agricultural Aspects (\% User)

\begin{tabular}{clrrrrrr}
\hline Rank & Type of Media & $\begin{array}{c}\text { Production } \\
\text { Techniques }\end{array}$ & Marketing & Policy & $\begin{array}{c}\text { Success } \\
\text { Story }\end{array}$ & $\begin{array}{c}\text { Human } \\
\text { Interest }\end{array}$ & Financing \\
\hline 1 & Television & 76.00 & 40.00 & 60.00 & 48.00 & 20.00 & 4.00 \\
2 & Mobile phone & 16.00 & 16.00 & 8.00 & 4.00 & 0.00 & 0.00 \\
3 & Radio & 20.00 & 44.00 & 0.00 & 0.00 & 0.00 & 4.00 \\
4 & Smartphone & 32.00 & 20.00 & 8.00 & 4.00 & 4.00 & 4.00 \\
\hline
\end{tabular}

Note: percentage of user represents the comparison number of media user compared with total surveyed farmers and one type of media can be used for multiple types of aspect

technical production information compared to the other aspects.

Additionally, the farmers already assumed that important knowledge could be accessed via several electronic media devices. They could access new information about the farming system on the television or radio and address their problem by using their smartphone (browsing the internet) or even ask their colleagues or extension workers about their problem through a mobile phone (SMS and making a phone calls).

Looking at information types, human interest and financing issues were still very limited to be accessed by farmers. The possibility is media only provide few information related those issues and or farmers have the other information sources such as direct contact with extension officers, farming groups, relatives, friends and neighbors

\section{Discussion}

While large attention has been given on macro and micro perspectives when studying ICTs as mentioned on the introduction part, this study can be categorized at the mezzo perspective on ICTs study. As it has been described on introduction part, macro perspectives of ICTs studies have been done by Mahant, et.al, (2012), Singh, et.al, (2017), Lokeswari (2016), Saidu, et.al, (2017), Purnomo and Lee (2010). The studies on micro perspectives of ICTs have been conducted by Ugwuishiwu, et.al, (2012), Gultom, et.al, (2016) and Setiowati, et.al, (2015). The concept of ICTs in previous studies was commonly in narrow understanding that ICTs refer to the internet.

This study has contributed to the mezzo aspect of ICTs include functions of ICTs; ownership, access and utilization of ICTs; and particular usage of ICTs on various agricultural activities, and ICTs are also been 
itemized in broader understanding not only focus on the internet. Function or use of electronic media by farmers and their household members in their daily life includes (1) entertainment, (2) education, and (3) obtaining various information. The categorization of electronic media usage for accessing various information covers social, cultural, economic, political, health, and the environment. Whereas the analysis on farmers uses on electronic media for accessing information and issues related to agricultural activities includes (1) technical production, (2) marketing, (3) policy, (4) success stories, (5) human interest stories, and (6) financing access. Data analysis and discussion have been also not only oriented on ICTs use and application but also consider the socio-economic and geographical characteristics.

The broader concept of ICTs combines the use of conventional electronic media and new electronic media which include television, radio, $\mathrm{CD} / \mathrm{VCD}$, telephone, mobile phone and internet. The application of broader concept which covers conventional electronic media and new media give important information on transformation pattern on information demand through electronic media used by farmers in the rural area.

The study result shows that the percentage of electronic media utilization both conventional media and new media for supporting agricultural related activities in the coastal farming area of Kulon Progo was considerably high. Access and utilization of ICTs have been on wide scope which was not only for using conventional electronic media including television, radio, $\mathrm{CD} / \mathrm{VCD}$; but also newly introduced electronic media such as telephone, mobile phone and internet.

To describe the linkages of the socio-economic characteristics of farmers in coastal agricultural areas with the use of ICTs to support various agricultural activities in detail in table 7 . ICTs used by farmers to support agricultural activities include television, radio, mobile phones and smartphones

Table 6. The linkage socioeconomic characteristics of the farmer and the use of ICTs for supporting farming activities in the research site (\%)

\begin{tabular}{|c|c|c|c|c|c|c|c|c|c|c|c|c|c|c|c|c|c|c|c|c|c|c|c|c|}
\hline \multirow{2}{*}{$\begin{array}{c}\text { Socio- } \\
\text { economics } \\
\text { characteristics }\end{array}$} & \multicolumn{4}{|c|}{ Production } & \multicolumn{4}{|c|}{ Marketing } & \multicolumn{4}{|c|}{ Policy } & \multicolumn{4}{|c|}{ Success Story } & \multicolumn{4}{|c|}{ Human Interest } & \multicolumn{4}{|c|}{ Financing } \\
\hline & $\mathrm{T}$ & $\mathrm{R}$ & MP & SP & $\mathrm{T}$ & $\mathrm{R}$ & MP & SP & $\mathrm{T}$ & $\mathrm{R}$ & MP & SP & $\mathrm{T}$ & $\mathrm{R}$ & MF & SP & $\mathrm{T}$ & $\mathrm{R}$ & MP & SP & $\mathrm{T}$ & $\mathrm{R}$ & MP & SP \\
\hline \multicolumn{25}{|l|}{ Age (Years Old) } \\
\hline $31-50$ & 44.0 & 8.0 & 8.0 & 24.0 & 32.0 & 12.0 & 40.0 & 20.0 & 40.0 & 8.0 & & 8.0 & 32.0 & 4.0 & - & 4.0 & 16.0 & - & & 4.0 & 4.0 & - & & - \\
\hline $51-70$ & 32.0 & 8.0 & 12.0 & 8.0 & 8.0 & 4.0 & 4.0 & - & 20.0 & - & & - & 16.0 & - & - & - & 4.0 & - & & - & - & - & & 4.0 \\
\hline
\end{tabular}

Formal Education

Elementary

\begin{tabular}{|c|c|c|c|c|c|c|c|c|c|c|c|c|c|c|c|c|c|c|c|c|c|}
\hline School & 12.0 & - & 4.0 & - & - & - & - & - & 4.0 & - & -- & - & - & - & - & - & - & -- & - & - & -4.0 \\
\hline Junior High & & & & & & & & & & & & & & & & & & & & & \\
\hline School & 24.0 & 12.0 & 16.0 & 12.0 & 12.0 & 8.0 & 8.0 & 8.0 & 20.0 & - & -- & 20.0 & - & - & - & 8.0 & - & -4.0 & - & - & - \\
\hline $\begin{array}{l}\text { Senior High } \\
\text { School }\end{array}$ & 36.0 & 4.0 & - & 20.0 & 28.0 & 8.0 & 36.0 & 12.0 & 36.0 & 8.0 & -8.0 & 24.0 & 4.0 & - & 4.0 & 8.0 & - & - & 4.0 & - & - \\
\hline University & 4.0 & - & - & - & - & - & - & - & - & - & $\ldots$ & 4.0 & - & - & - & 4.0 & - & - & - & - & $\ldots$ \\
\hline
\end{tabular}

Farming Experience

(Years)

\begin{tabular}{|c|c|c|c|c|c|c|c|c|c|c|c|c|c|c|c|c|c|c|c|c|c|}
\hline $1-20$ & 44.0 & 8.0 & 16.0 & 16.0 & 24.0 & 8.0 & 24.0 & 12.0 & 36.0 & - & - & 20.0 & - & - & - & 12.0 & - & -4.0 & 4.0 & - & -4.0 \\
\hline $21-35$ & 28.0 & 8.0 & 4.0 & 16.0 & 16.0 & 8.0 & 20.0 & 8.0 & 24.0 & 8.0 & -8.0 & 28.0 & 4.0 & - & 4.0 & 8.0 & - & - & - & - & - - \\
\hline$>35$ & 4.0 & - & - & - & - & - & - & - & - & - & $\ldots$ & - & - & - & - & - & - & $\ldots$ & - & - & - - \\
\hline
\end{tabular}

Household Monthly Income (000 IDR)

\begin{tabular}{|c|c|c|c|c|c|c|c|c|c|c|c|c|c|c|c|c|c|c|c|c|c|}
\hline$<3.000$ & 4.0 & - & - & - & 4.0 & - & 4.0 & - & 4.0 & - & - & - & - & - & - & - & - & - & - & - & -- \\
\hline $3.000-6.000$ & 28.0 & - & 8.0 & 4.0 & 16.0 & 4.0 & 20.0 & 8.0 & 20.0 & 4.0 & -4.0 & 16.0 & - & - & - & 12.0 & - & -4.0 & 4.0 & - & - \\
\hline$>6.000$ & 44.0 & 16.0 & 12.0 & 28.0 & 20.0 & 12.0 & 20.0 & 12.0 & 36.0 & 4.0 & -4.0 & 32.0 & 4.0 & - & 4.0 & 8.0 & - & -- & - & - & -4.0 \\
\hline
\end{tabular}

Note: $\mathrm{T}=$ Television, $\mathrm{R}=$ Radio, $\mathrm{MP}=$ Mobile

Phone, $\mathrm{SP}=$ Smart Phone 
Based on table 6 , it is generally illustrated that young group farmers are more active in using ICTs to support agricultural activities where television is still considered important to serve agricultural information needs, mobile phone and smartphones have been used by several young farmers to access information related to production and marketing of products. Higher educated farmers (high school and university) in addition to utilizing television have also utilized mobile phones and smartphones to access agricultural production information, prices and policies. Farmers with relatively low education still rely on television and some start using mobile phones primarily to access information on agricultural production. The group of farmers with relatively new farming experience, in addition to using television also began to use mobile phones and smartphones to access production and marketing information while other information was still using television. Farmers with longer farming experience rely on telecommunications and some have started using mobile phones. Farmers with higher income groups, besides utilizing telecommunications, have started using mobile phones and smartphones to access production and marketing information. A small number of farmers also use mobile phones and smartphones for other agricultural information.

Geographical condition of research site which is located in the flat coastal area where access and transportation have been greater developed to some extent also could improve the higher mobility of local farmers and rural people. In addition, since the early 2000s expansion and development of the electricity network and telecommunication network have also improved very much due to located in the better access area. Therefore, infrastructures related to ICTs services have been getting remarkably developed and could enhance better access to rural people on ICTs usage. One of the young farmers Mr. Sut (36 years old) stated that over the last 10 years the electricity and telecommunications networks in the village have considerably improved. In the village there are several Base Transceiver Stations (BTS) that have been installed and almost every hamlet is served by one BTS so that telecommunications access is generally good. One problem that sometimes arises is the relatively low access speed.

The economic condition of farming households, to some extent, likely contributes to the electronic media ownership and utilization. Electronic media is recognized as relatively expensive, and additionally, its utilization requires an additional cost. Farming households that have a higher income from cultivated crops have a greater opportunity to fully use electronic media for supporting their farming activities. As noted on previous data, the largest part of farming households belonged to a community whose income was above the regional minimum wage. By managing commercial horticulture agribusiness, coastal farmers could get a higher income, therefore they could afford to defray various farming household needs including information access (ICTs) cost. A key informant Mr. Skr (59 years old) mentioned that regarding telecommunications access costs, it is generally perceived as quite affordable. With the cost of purchasing an internet package of around 100.000 IDR per month, it can be easily covered by farmers who get quite a large amount of monthly income from the horticultural farming business.

The progressivity of the farmers, which to some extent is represented by their age and educational background, also becomes an important factor when considering the access and usage of ICTs. This study shows that $68 \%$ of the farmers in the research site are young (aged 31-50 years old). The young age enabled the farmers to access electronic media, and especially new media, easily because they possessed a broad, modern insight and have the ability to operate ICT devices. From an in-depth interview with Farmer Group Leader, it has been informed that some high education young farmers who graduated from universities have involved directly in commercial farming management in coastal area.

Based on the use of media to gain agricultural information by farmers, some electronic media, such as mobile phones and televisions were regarded as the most important media used among farmers. The mobile phone has been perceived to greatly contribute to obtaining information immediately and accurately. The farmers in the coastal areas of Kulon Progo, who grow a high percentage of perishable horticulture crops, need quick and accurate information, especially for distributing and marketing of the products. The mobile phone began as an important communication tool to facilitate the process of horticultural crop marketing. Through the mobile phone, farmers were able to access the market network. ICTs use especially mobile phones through phone call and SMS have been utilized for facilitating and connecting buyers from other cities with a committee of auction market of chili in the research site. The mobile phone has been also applied for organizing and collecting of chili among farmer group members on every scheduled market auction of chili.

Increased use of the mobile phone by the Kulon Progo farmers was likely due to the increased economic status as a result of the cultivated commercial commodity. The higher price of horticulture crops to some extent has improved household income and farming household members have more chances to allocate a particular part of their income to pay access for mobile phones and internet.

In short, instead of using the television and radio as conventional electronic media, the newly emerging electronic media, especially the mobile phone and smartphone through the internet, became very prominent in responding to the dynamics of agricultural problems in the coastal areas. The new 
media provide fast and accurate information. In the newly developed coastal farming area of Kulon Progo Regency, where most of the farmers grow horticultural crops characterized as a high risk and having a high price, the farmers have started to utilize mobile phones to exchange short messages and, to some extent, use the internet for accessing the market situation of cultivated crops.

The socio-economic aspects of farmers in the research site may also contribute to the farmers' choice to use new media technologies. Mobilized by the relatively young and well-educated farmers, the higher household incomes and better rural infrastructure and telecommunication networks facilitate a better opportunity for the farmers to use new media (ICTs) to overcome various problems in agricultural activities. The use of ICTs in supporting farming business in the coastal areas has been important especially for speeding up information exchange and facilitating farming business to be more efficient as it was also advocated by Vosough, Eghtedari and Binaian (2015).

Improvement of ICTs access by farmers needs the appropriate development of infrastructures and telecommunication networks in rural areas. Practically ICTs development should be supported by the central and local governments and by the private sector to create a better atmosphere for agricultural development activities. Additionally, telecommunication network maintenance and electrification would also facilitate access to ICT utilization, especially operating mobile phones and smartphones in rural areas. Friendly use of contents and operating procedures of ITCs and the provision of various types of needed information will be also crucial consideration on ICTs development strategies for farming communities in the rural areas. The important of ICTs infrastructure development and provision of ICTs services for improving information access of farmers in the rural areas has also been suggested by Mahant, et al., (2012), Lokeswari (2016) and Saidu, et al., (2017).

A comprehensive study on the pattern of the usage of ICTs among farmers and determinant influencing factors of media access would be an important research topic in the future. Due to farming types of characteristics in rural Indonesia are also important aspect; those could be clustered into commercial farming, food crops farming, plantation, fisheries, livestock, forestry, etc. Access pattern of new media can also be studied through focusing on access frequency, cost of media access, types of information or information content, etc.

\section{Conclusion}

The majority of the farmers in the research site had similar access and utilization of electronic media which cover a wide scope of ICTs include conventional electronic media and newly developed electronic media. To some extent, electronic media usage by rural people has been remarkably expanded which includes televisions, radios, mobile phones, and smartphones, which were mostly privately owned by farmers compared with printed media ownership. Electronic media was generally utilized to gain information related to social, cultural, economic and environmental issues. To gain this information, electronic media that were commonly used included televisions and radios (conventional electronic media), mobile phones and smartphones (new electronic media).

New media such as internet and short message service through mobile phones and smartphones has become increasingly popular among coastal farmers in the research site who grow commercial horticultural crops, particularly to access market information and new innovative technologies. The modernization of agricultural development in the coastal areas to some extent has been supported by compatible ICTs access.

Farmers who use new media in the coastal area are characterized as being young and well-educated, have a higher income, and experience better infrastructure and telecommunication networks. Generally, ICTs use by farmers for supporting farming activities is mostly limited due to the technical production aspects of agriculture. The better geographical conditions could improve better expansion and development of electricity networks and telecommunication networks which in turn could improve ICTs services for fulfilling the demand for various information and innovation of rural people and for improving the performance of agribusiness development in the rural areas.

\section{Acknowledgment}

The authors would like to thank the great support of the research assistants for assisting the field survey (Ade Intan Cristian, Ani Dwi Wimatsari, Paksi Mei Penggalih, Sylvatra Puspita Sari, and Faidza Rika Chandika), Sekar Dewinda has prepared the map of research site and two anonymous reviewers who gave fruitful and insightful comments. This study partly was funded by Research Grant No.050112017 from the Faculty of Agriculture, Universitas Gadjah Mada for the fiscal year 2016. Some parts of the initial version of the paper have been presented on the International Conference of Science and Technology (ICST)Geomaritime UGM 2017 and $9^{\text {th }}$ International Graduate Students and Scholars Conference in Indonesia (IGSI) UGM 2017.

\section{References}

Amin, M., Sugiyanto, Sukesi, K., and Ismadi. (2013). The Effectiveness of Cyber-Extension-Based Information Technology to Support Agricultural Activities in Donggala Regency, Central Sulawesi Province, Indonesia. International Journal of Asian Social Science, 3(4), 882-889. https://econpapers.repec.org/ scripts/redir.pf?u=http $\% 3 \mathrm{~A} \% 2 \mathrm{~F} \% 2 \mathrm{Fwww}$.aessweb. 
com\%2Fdownload.php\%3Fid\%3D1953;h=repec:asi:ijoa ss:2013:p:882-889

Bunnell, Tim, (2009), Human Geographies in Decentralized Indonesia, Indonesian Journal of Geography (IJG) Vol. 41, No.2, December 2009 (189-200); https://jurnal.ugm. ac.id/ijg/article/view/2271

Creswell, J.W and Clark, V.L.P, (2010), Designing and Conducting Mixed Methods Research, SAGE Publications.

Das, Kaushik, et.al., (2016), Unlocking Indonesia' Digital Opportunity, McKinsey \& Company, https://www. mckinsey.com/ /media/McKinsey/Locations/ Asia/Indonesia/Our\%20Insights/Unlocking\%20 Indonesias\%20digital\%20opportunity/Unlocking Indonesias digital opportunity.ashx (Accessed on October 2, 2019)

FAO, (2019), Information and Communication Technologies (ICTs), http://aims.fao.org/information-andcommunication-technologies-ict (Accessed on February $\underline{19,2019)}$

Gultom, D.T., Sumardjo, Sarwoprasodjo, S. and Muljono, P., (2016), The Roles of Cyber Extension Communication Media in Strengthening Horticulture Farmers in Facing Globalization in Lampung Province, Indonesia, International Journal of Sciences: Basic and Applied Research (IJSBAR) Vol. 26(2): 104-117. http://gssrr.org/ index.php?journal =JournalOfBasicAndAppliederpage $=a r$ ticled o $p=$ downloaderpath $\% 5 B \% 5 D=5420$ e path $\% 5 B \% 5$ $\underline{D=2816}$

Guntoro, B, Subejo and Sazali, H, (2016), Information Access Capability of Goat Farmers in Purworejo Indonesia. Information, 19: (6A), 1819-1826. https://repository. ugm.ac.id/136632/1/Information $\% 20$ Access $\% 20$ Capability\%20of\%20Goat\%20Farmers\%20in\%20 Purworejo\%20Indonesia.pdf

Harini, Rika; Susilo, Bowo and Nurjani, Emilya, (2015), Geographic Information System-Based Spatial Analysis of Agricultural Land Suitability in Yogyakarta, Indonesian Journal of Geography (IJG) Vol. 47, No.2, December 2015 (171-179); https://jurnal.ugm.ac.id/ijg/ article/view/9260

Khan, G.A, (2013), Information Regarding Agronomic Practices and Plant Protection Measures Obtained by the Farmers through Electronic Media, The Journal of Animal and Plant Science, 23: (2), 647-650; https:// www.cabdirect.org/cabdirect/abstract/20133246708

Khan, G.A., Muhammad, S., Chaudhry, K M., Khan, M.A, (2010), Present and Future Preference of Electronic Media as Agricultural Information Sources by Farmers, Pak Journal of Agri. Sci, 42(2), 166-172; https://www. cabdirect.org/cabdirect/abstract/20103196274

Leeuwis, C. (2013). Communication for rural innovation: rethinking agricultural extension. John Wiley \& Sons.

Lokeswari, K., (2016), A Study of The Use of ICT Among Rural Farmers, International Journal of Communication Research Vol. 6(3):232-238. https://www.questia.com/ library/journal/1P3-4282489801/a-study-of-the-use-ofict-among-rural-farmers

Mahant, M., Shukla, A., Dixit, S. and Patel, D., (2012) Uses of ICT in Agriculture. International Journal of Advanced Computer Research Vol. 2(1):46-49. https://www. researchgate.net/publication/265351125 Uses of ICT in agriculture
Ministry of Communication and Information of Indonesia, (2015), Utilization and Empowerment of Information and Communication Technology for Farmers. https://balitbangsdm. kominfo.go.id/?mod=publikasi\&a=dl\&page $\mathrm{id}=148 \&$ cid=29\&download $\mathrm{id}=114$. (Accessed on February, 17, 2019).

Neuman, L, (2009), Social Research Methods: Qualitative and Quantitative Approaches (7th Edition), Pearson, New York.

Purnomo, S., \& Lee, Y.-H. (2010). An assessment of readiness and barriers towards ICT program implementation: Perceptions of agricultural extension officers in Indonesia. International Journal of Education and Development Using ICT Vol.6(3):19-36. Retrieved from https://www.learntechlib.org/p/42380

Saidu, A., Clarkson, A.M., Adamu, S.H., Mohammed, M., Jibo, I., (2017), Application of ICT in Agriculture: Opportunities and Challenges in Developing Countries, International Journal of Computer Science and Mathematical Theory Vol.3(1):8-18. https://iiardpub. org/get/IJCSMT/VOL.\%203\%20NO.\%201\%202017/ Application\%20of\%20ICT.pdf

Salemink, K., Strijker, D., \& Bosworth, G. (2017). Rural Development in The Digital Age: A Systematic Literature Review on Unequal ICT Availability, Adoption, and Use in Rural Areas. Journal of Rural Studies Vol.54: 360371. https://www.sciencedirect.com/science/article/pii/ S0743016715300176?via\%3Dihub

Setiowati, R., Hartoyo, Daryanto, H.K. and Arifin, B, (2015), The Effects of ICT Adoption on Marketing Capabilities and Business Performance of Indonesian SMEs in The Fashion Industry, The Business and Management Review, Vol. 6(4): 297-311. http://www.abrmr.com/myfile/ conference proceedings/Con_Pro 66154/2015iacp48. $\underline{\mathrm{pdf}}$

Singh, S., Ahlawat, S., and Sanwal, S., (2017), Role of ICT in Agriculture: Policy Implications, Orient. J. Comp. Sci. and Technol: 10(3). https: https://www. computerscijournal.org/vol10no3/role-of-ict-inagriculture-policy-implications/

Soriano, C. R. R. (2007). Exploring the ICT and Rural Poverty Reduction Link: Community Telecenters and Rural Livelihoods in Wu'an, China. The Electronic Journal of Information Systems in Developing Countries, 32(1), 1-15. https://doi.org/10.1002/j.1681-4835.2007. tb00220.x

Subejo, (2016), Use of ICTs on Agro Sectoral Development in Indonesia, Proceedings of National Conference on Development Communication, Brawijaya University Malang (in Indonesian).

Sulthoni, M. A., Laksono, P., Ishiura, D., Amemiya, S., \& Umejima, M. (2013). Key Parameters for Developing Agricultural Electronics Service in Indonesia. Proceedings of ICEID.

Supriyanto, et.al,.(2013), Adaptation Strategy for Climate Change in Coastal Area of Yogyakarta, Laboratory of Agricultural Extension and Communication UGMPintal Publishing (in Indonesian).

Ugwuishiwu C.H, Udanor C. and Ugwuishiwu B.O, (2012), Application of ICT in Crop Production, International Journal of Soft Computing and Engineering (IJSCE) 
Vol.2(4):227-231. http://www.ijsce.org/wp-content/ uploads/papers/v2i4/D0951082412.pdf

Vosough, Ali; Eghtedari, Niusha; Binaian, Akram, (2015), Factors Affecting ICT Adoption in Rural Area: A Case Study of Rural users in Iran, Research Journal and Fisheries and Hydrobiology 10(10) June 2015, 611-616; https://pdfs.semanticscholar.org/5813/115a26fbd79a38a 63b31c65fad3c7fe293d2.pdf

WIKI NUS Edu, (2019), History of ICT, https://wiki.nus. edu.sg/display/cs1105groupreports/History+of + ICT (Accessed on February 19, 2019) 